\title{
A study of seed micromorphology in the genus Ophrys (Orchidaceae)
}

\author{
Pablo Galán Cela ${ }^{1}$, Irene Seligrat ${ }^{2}$, Emma Ortúñez ${ }^{2}$, Roberto Gamarra ${ }^{2, *}$, Alejandro Vivar ${ }^{3}$ \& Antonio Scrugli ${ }^{4}$ \\ ${ }^{1}$ Departamento de Producción Vegetal, Botánica y Protección Vegetal, Universidad Politécnica de Madrid, E-28040 Madrid, Spain; pablo.galan@upm.es \\ 2DDepartamento de Biología, Universidad Autónoma de Madrid, E-28049 Madrid, Spain; emma.ortunez@uam.es; roberto.gamarra@uam.es \\ ${ }^{3}$ Departamento de Ciencias Básicas Aplicadas a la Ingeniería Forestal, Universidad Politécnica de Madrid, E-28040 Madrid, Spain; alejandro.vivar@upm.es \\ ${ }^{4}$ Dipartimento di Scienze Botaniche, Università di Cagliari, I-09124 Cagliari, Italy; scrugli@unica.it
}

\begin{abstract}
Galán Cela, P., Seligrat, I., Ortúñez, E., Gamarra, R., Vivar, A. \& Scrugli, A. 2014. A study of seed micromorphology in the genus Ophrys (Orchidaceae). Anales Jard. Bot. Madrid 71(2): e008

Seed micromorphology of 19 taxa of the genus Ophrys have been studied using SEM and light microscope. Quantitative data (length and width of seed and embryo, number of testa cells along the longitudinal axis, volume of seed and embryo, and percentage of free air space), as well as qualitative characters (seed shape, features of the anticlinal and periclinal walls, ornamentation and colour) were analysed. All the seeds are fusiform, with an asymmetrical basal pole, the periclina walls of the medial cells have parallel and transverse to slanting ridges, and raised anticlinal walls. Statistical analyses show two large clusters according to the volumes of seed and embryo. Our results support the monophyly of the genus and their recent diversification, however, seed features are not congruent with the recognition of sections and groups within Ophrys.
\end{abstract}

Keywords: testa cells, periclinal walls, SEM, statistical analysis.

\section{INTRODUCTION}

The genus Ophrys L. (Orchidaceae, Orchidinae) is distributed from the Canary islands to the Near Orient, with great diversification in the Mediterranean basin (Pridgeon \& al., 2001; Delforge, 2006; Pedersen \& Faurholdt, 2007). It is well characterized by their labellum, which resembles the body or some organs of different insects, and it is linked with the mechanism of pollination (pseudocopulation).

Their monophyly is strongly supported by morphological and molecular data (Soliva \& al., 2001; Bateman \& al., 2003; Bernardos \& al., 2005), with Serapias L. and Anacamptis Rich. as the closest relatives genera. No intergeneric hybrids with other representatives of the subtribe Orchidinae have been found, however, interspecific hybridization is widespread in the field, and perhaps, several taxa may be of hybrid origin (Pedersen \& Faurholdt, 2007).

The taxonomy of this genus remains difficult, with a profusion of taxa along the distribution range, mainly in Greece and Turkey. Several authors have contributed to the taxonomy of the genus (Godfery, 1928; Nelson, 1962; Del Prete, 1984; Baumann \& Künkele, 1986; Devillers \& Devillers-Terschuren, 1994; Delforge, 2006; Pedersen $\&$ Faurholdt, 2007). The lack of consensus between orchidologists has resulted in discrepancies as to the number of

\section{Resumen}

Galán Cela, P., Seligrat, I., Ortúñez, E., Gamarra, R., Vivar, A. \& Scrugli, A. 2014. Un estudio de la micromorfología de las semillas en el género Ophrys (Orchidaceae). Anales Jard. Bot. Madrid 71(2): e008

Se ha estudiado la micromorfología de semillas de 19 taxones del género Ophrys mediante el empleo de microscopio óptico y electrónico de barrido. Se han analizado datos cuantitativos (longitud y anchura de la semilla y del embrión, número de células en la testa a lo largo del eje longitudinal, volumen de la semilla y del embrión, y porcentaje de espacio aéreo libre) y cualitativos (morfología de la semilla, características de sus paredes anticlinales y periclinales, ornamentación y color). Todas las semillas analizadas son fusiformes, con polo basal asimétrico, ornamentación de las paredes periclinales formada por costillas paralelas y transversales a oblicuas, y paredes anticlinales prominentes. Los análisis estadísticos revelan dos grandes cluster según los valores de los volúmenes de la semilla y el embrión. Nuestros resultados apoyan la monofilia del género y su reciente diversificación, sin embargo, los caracteres micromorfológicos de las semillas no son congruentes con el reconocimiento de secciones y grupos dentro del género Ophrys.

Palabras clave: células de la testa, paredes periclinales, MEB, análisis estadístico.

taxa, for instance, Delforge (2006) recognised 252 species throughout their distribution range, whilst Pedersen \& Faurholdt (2007) mentioned 19 species in Europe, many of them including infraspecific taxa (subspecies and varieties), and several hybrids.

Several authors have considered the subdivision of the genus in sections, complexes, groups and subgroups, based on floral characters or adaptations to a specific pollinator (Paulus \& Gack, 1990; Devillers \& Devillers-Terschuren, 1994; Delforge, 2006). In these publications, the sections Ophrys and Pseudophrys Godfery were recognised. The monophyletism of the section Pseudophrys have been corroborated by morphological (Devillers \& DevillersTerschuren, 1994), karyological (Greilhuber \& Ehrendorfer, 1975; D’Emerico \& al., 2005) and molecular data (Soliva \& al., 2001; Bateman \& al., 2003; Bernardos \& al., 2005; Inda \& al., 2010), but these results are not congruent with the whole of the section Ophrys (Soliva \& al., 2001; Bateman $\&$ al., 2003), or with the 32 groups accepted by Delforge (2006). Molecular analyses have highlighted a recent evolution of the genus and a rapid colonization throughout its distribution (Soliva \& al., 2001; Bateman \& al., 2003; Inda $\&$ al., 2012). According to Pedersen \& Faurholdt (2007), the classification and phylogeny of this genus is confusing and needs new insights. 
Preceding studies on orchid seeds have demonstrated the phylogenetic value of certain quantitative and qualitative characters (Clifford \& Smith, 1969; Barthlott \& Ziegler, 1981; Tohda, 1983; Molvray \& Kores, 1995). In addition, recent publications (Gamarra \& al., 2007; Gamarra \& al., 2008; Gamarra \& al., 2012) emphasize the strong support between the seed micromorphology and the molecular analyses published in the subtribe Orchidinae (Bateman \& al., 2003).

Barthlott (1976) compared the seeds of the genera Opbrys and Serapias, demonstrating the taxonomic value of the seed shape and the tipology of the trabeculae in the testa cells to distinguish both genera. Also, he mentioned the difficulty of distinguishing the seeds within Ophrys. Mrkvicka (1994) published qualitative and quantitative data of O. apifera Huds., O. holosericea (Burm. fil.) Greuter, O. insectifera L. and O. sphegodes Mill. Recently, Aybeke (2007) has studied 8 taxa from southeastern mediterranean countries, concluding that all taxa showed reticulated surfaces in the testa cells.

The main aim of our survey is to study and analyse the seed micromorphology of selected species of Ophrys, based on qualitative and quantitative data. A statistical and a SEM survey of seeds were conducted to investigate patterns of infrageneric variability in the genus. Finally, to demonstrate a correlation between our results and Ophrys lineages recognised in previous publications on the basis of morphological and molecular data.

\section{MATERIAL AND METHODS}

Seeds of 19 species were obtained from mature capsules collected in the field. Fresh seeds were dried for at least one month and stored in small paper envelopes. Specimens for seed morphological analyses were deposited in the herbaria MAUAM and CAG (acronyms according to Thiers, 2012). Voucher specimens, with their circumscription to sections and groups according to Delforge (2006), are listed in Table 1.

For scanning electron microscopy observations, the samples were mounted on SEM stubs and coated with gold in a sputter-coater (SEM Coating System, Bio-Rad SC 502). The seeds were examined with a Philips XL30, with a filament voltage of $20 \mathrm{kV}$. Qualitative data such as seed shape and testa cell features (sculpturing, morphology of cells and the anticlinal and periclinal walls) were analysed. In addition, an average of 30 seeds from each specimen were analysed using a light microscope, previously mounted with PVA (polyvinilic alcohol). Quantitative variables like seed size (length and width), number of cells along the longitudinal axis, embryo morphology and size (length and width), and seed colour (in subjective terms) were recorded. Furthermore, the length/width ratio $(\mathrm{L} / \mathrm{W})$, the percentage of free air space and the seed and embryo volumes were estimated. The terminology and methods adopted were those of Arditti \& al. (1979), Barthlott \& Ziegler (1981), Molvray \& Kores (1995), Chase \& Pippen (1988), Arditti \& Ghani (2000). Statistical analyses were performed by SPSS 17 for Windows, after logarithmic transformation of the volume data. Ward's method with Euclidean distances was conducted for cluster analysis.

\section{RESULTS}

\section{Qualitative data}

In all the analyzed species, the seed shape is fusiform (Fig. 1A), slightly wider in the middle or towards the apical pole where the ellipsoidal embryo is located. Generally, the seeds show a more or less truncated apical pole (Fig. 1B) and an asymmetric basal pole (Fig. 1C). Cells of both poles are polygonal and shorter (Fig. 1B-C), whereas medial cells are elongated (Fig. 1D).

Medial testa cells are longitudinally oriented. They have predominantly parallel ridges on their periclinal walls, ranging in orientation from transversal to slanting (Fig. 2A-C). Adhesion zones between cells show a distinct lamella (Fig. 2B). Anticlinal walls are longitudinal and straight, strongly raised, and the outer periclinal surface is generally concave (Fig. 2C, D). Seed colour ranges from brown-yellowish to dark brown. The embryo is brown in colour.

\section{Quantitative data}

Table 2 shows the length and width of seed and embryo, the number of cells along the longitudinal axis, and the length/width ratio. Average values of the seed and embryo volumes, the percentage of free air space and the colour of testa are shown in Table 3.

The maximum L/W ratio was observed in O. chestermanii, and the minimum in $O$. lutea, which agrees with the seed length measurements. The number of testa cells along the longitudinal axis varies from 4 to 8 . In general, the longest seeds have the highest number of testa cells. The highest seed and embryo volume were measured in $O$. dyris and O. scolopax, respectively. The lowest average values for these variables were found in $O$. sicula. Fifteen of the species analysed had more than $70 \%$ free air space, however, in O. funerea and O. lutea, the values did not exceed $50 \%$.

The quantitative data do not verify the required hypothesis for analysis of variance, because significant differences in the standard deviations of the variables have been found. Even, the coefficients of skewness and kurtosis indicate the absence of normality in some variables. Analyzing the variables Sv (Seed volume) and Ev (Embryo volume), the statistical analysis revealed that the species fall into two groups. Higher volumes were found in Ophrys dyris, O. dianica, O. chestermanii, O. eleonorae, $O$. scolopax and $O$. morisii, and lower volumes in the rest of taxa (Fig. 3).

Using Ward's method with euclidean distance, two large clusters were produced by the dendrogram (Fig. 4), one including the subgroups A (Ophrys dyris-1, O. dyris-2, $O$. dianica-7, $O$. chestermanii-17) and $\mathrm{B}(O$. eleonorae-3, O. eleonorae-4, O. dianica-6, O. scolopax-18, $O$. morisii-19), and the other with the subgroups $C$ (O. funerea-5, O. lutea-9), D (O. fusca-8, O. speculum-12, O. bombyliflora-14, O. castellana-20, O. sphegodes-22, 
Table 1. List of selected species with voucher specimens and codes. Sections and groups according to Delforge (2006).

\begin{tabular}{|c|c|c|c|}
\hline Species & Section & Group & Voucher \\
\hline O. funerea Viv. & Pseudophrys & funerea & Italy, Sardinia: Laconi, A. Scrugli (CAG) \\
\hline O. fusca Link & Pseudophrys & fusca & Spain, Badajoz: Los Santos de Maimona, R. Gamarra 227 (MAUAM) \\
\hline \multirow[t]{2}{*}{ O. eleonorae Devillers-Tersch. \& Devillers } & Pseudophrys & iricolor & Italy, Sardinia: Laconi, A. Scrugli (CAG) \\
\hline & & & Italy, Sardinia: Tuvumannu, A. Scrugli (CAG) \\
\hline O. lutea Cav. & Pseudophrys & lutea & Spain, Córdoba: Benamejí - El Tejar, R. Gamarra 17 (MAUAM) \\
\hline O. sicula Tineo & Pseudophrys & lutea & Italy, Sardinia: Laconi, A. Scrugli (CAG) \\
\hline \multirow[t]{2}{*}{ O. dyris Maire } & Pseudophrys & omegaifera & Spain, Toledo: Orgaz - Marjaliza, R. Gamarra 65 (MAUAM) \\
\hline & & & Spain, Toledo: Orgaz - Marjaliza, R. Gamarra 225 (MAUAM) \\
\hline O. vasconica (O. \& E. Danesch) P. Delforge & Pseudophrys & omegaifera & Spain, Navarra: Munarriz, P. Galán 4488 (MAUAM) \\
\hline \multirow[t]{2}{*}{ O. dianica M.R. Lowe \& al. } & Pseudophrys & subfusca & Spain, Alicante: Teulada, P. Galán 4303 (MAUAM) \\
\hline & & & Spain, Alicante: Benisivá - Planes, P. Galán 4304 (MAUAM) \\
\hline O. apifera Huds. & Ophrys & apifera & Italy, Sardinia: Laconi, A. Scrugli (CAG) \\
\hline O. morisii (Martelli) Soó & Ophrys & argolica & Italy, Sardinia: Laconi, A. Scrugli (CAG) \\
\hline O. chestermanii (J.J. Wood) Gölz \& H.R. Reinhard & Ophrys & bornmuelleri & Italy, Sardinia, Domusnovas, A. Scrugli (CAG) \\
\hline O. castellana Devillers-Tersch. \& Devillers & Ophrys & incubacea & Spain, Cuenca: Laguna del Marquesado, R. Gamarra 154 (MAUAM) \\
\hline O. incubacea Bianca & Ophrys & incubacea & Italy, Sardinia: Cagliari, A. Scrugli (CAG) \\
\hline O. insectifera L. & Ophrys & insectifera & Spain, Barcelona: Borredà, R. Gamarra 416 (MAUAM) \\
\hline O. scolopax Cav. & Ophrys & scolopax & Spain, Madrid: Redueña, R. Gamarra 372 (MAUAM) \\
\hline O. speculum Link & Ophrys & speculum & Italy, Sardinia: Laconi, A. Scrugli (CAG) \\
\hline O. sphegodes Mill. & Ophrys & sphegodes & Spain, La Rioja: Fonzaleche, P. Galán 4490 (MAUAM) \\
\hline O. bombyliflora Link & Ophrys & tenthredinifera & Italy, Sardinia: Tuvixeddu, A. Scrugli (CAG) \\
\hline
\end{tabular}

O. vasconica-11) $\mathrm{E}(O$. sicula-10) and $\mathrm{F}(O$. insectifera-15, O. apifera-16, O. tenthredinifera-13, O. incubacea-21).

\section{DISCUSSION}

Our micromorphological study reveals a strong concordance in the qualitative features of the seeds in the genus Ophrys. The fusiform shape has been observed in many genera of the subtribe Orchidinae (Barthlott \& Ziegler, 1981;
Mrkvicka, 1994; Gamarra \& al., 2007; Gamarra \& al., 2012). We have found a set of characters which allow us to recognise the seeds as Ophrys-type. These are characterized by the asymmetry of the basal pole, the strong concavity of the testa cells with raised anticlinal walls and a distinct lamella. If we compare with the variation observed in other genera, this suite of qualitative data support the monophyly of the genus. Furthermore, all the species show the same sculpture pattern of the periclinal walls, with parallel ridges, only varying
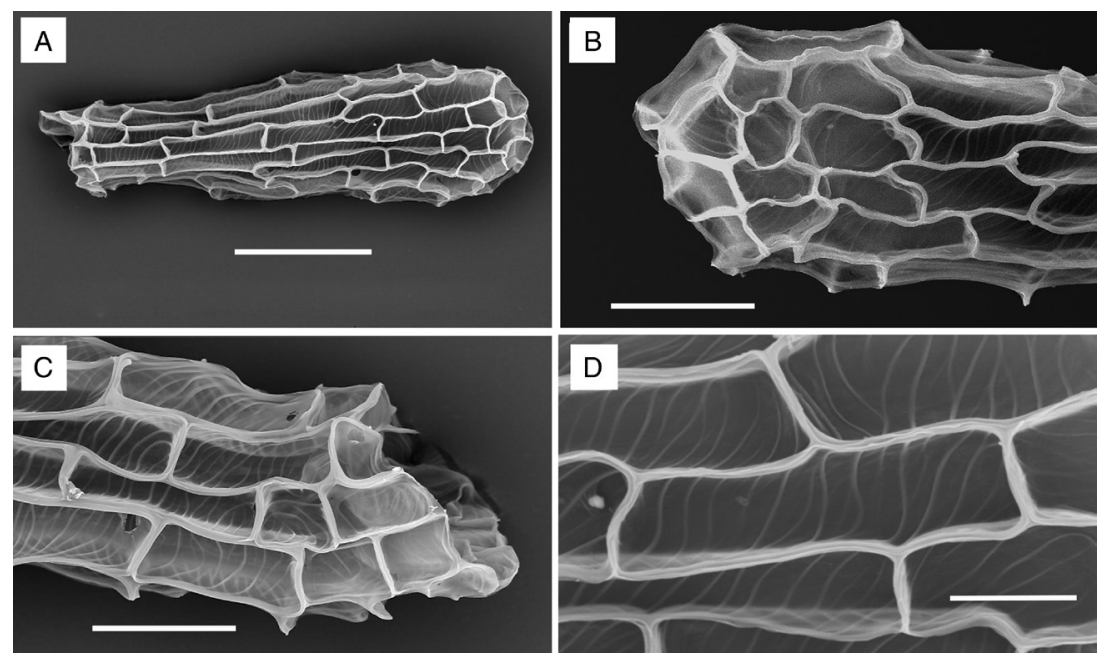

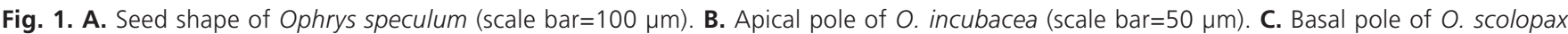
(scale bar=50 $\mu \mathrm{m}$ ). D. Medial cells of $O$. speculum (scale bar=20 $\mu \mathrm{m}$ ). 

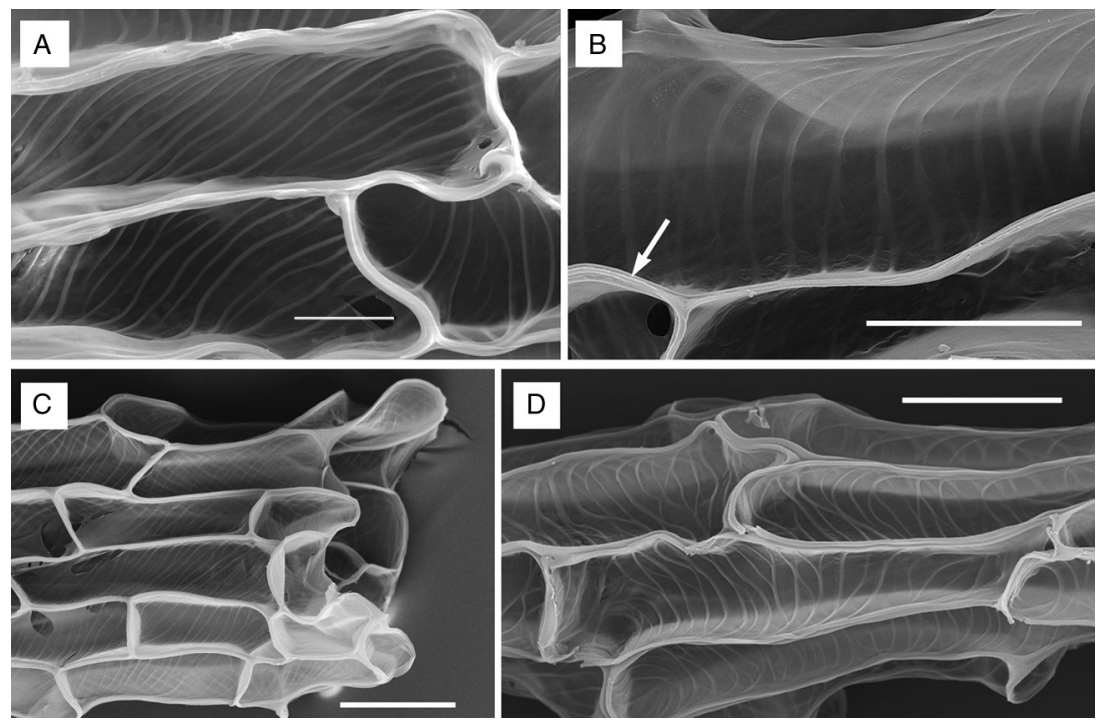

Fig. 2. A. Periclinal walls of the medial cells with slanting ridges in Ophrys morisii (scale bar $=20 \mu \mathrm{m}$ ). B. Adhesion zones with lamella in 0 . vasconica $($ scale bar=20 $\mu \mathrm{m})$. C. Basal pole of $O$. tenthredinifera (scale bar=50 $\mu \mathrm{m}$ ). D. Anticlinal and periclinal walls of medial cells showing the strong concavity of testa cells in O. scolopax (scale bar $=50 \mu \mathrm{m}$ ).

in the orientation, from transverse to slanting. This feature is not congruent with the observation of the reticulate surface described by Aybeke (2007). Barthlott (1976) states that testa cells of Ophrys can be clearly distinguished of those of Serapias, which show slanting, dense and thin ridges in the periclinal walls. The clear separation with related genera is not mirrored in within-genus variation. In Ophrys, unlike other genera such as Dactylorbiza Neck. ex Nevski

Table 2. Average values of length and width of seed and embryo, length/width ratio of the seed, and number of cells along the longitudinal axis of the taxa analysed.

\begin{tabular}{|c|c|c|c|c|c|c|c|}
\hline Species & Code & seed length $(\mu \mathrm{m})$ & seed Width $(\mu \mathrm{m})$ & $\begin{array}{l}\text { Ratio length/ } \\
\text { width }\end{array}$ & $\begin{array}{l}\text { Number } \\
\text { of cells }\end{array}$ & $\begin{array}{c}\text { embryo length } \\
(\mu \mathrm{m})\end{array}$ & $\begin{array}{c}\text { embryo Width } \\
(\mu \mathrm{m})\end{array}$ \\
\hline O. dyris & 1 & $669.83 \pm 93.19$ & $206.5 \pm 22.71$ & $3.24 \pm 0.70$ & $5-7$ & $155.33 \pm 4.38$ & $110 \pm 10.42$ \\
\hline O. dyris & 2 & $625.17 \pm 65.91$ & $185.67 \pm 27.88$ & $3.37 \pm 0.65$ & $5-7$ & $154.83 \pm 12.63$ & $106.67 \pm 12.48$ \\
\hline O. eleonorae & 3 & $511.17 \pm 67.72$ & $173.17 \pm 21.83$ & $2.95 \pm 0.60$ & $5-6$ & $154.17 \pm 24.25$ & $115.83 \pm 17.47$ \\
\hline O. eleonorae & 4 & $591.67 \pm 64.24$ & $169 \pm 17.78$ & $3.50 \pm 0.15$ & $5-7$ & $155.33 \pm 14.26$ & $115.33 \pm 12.66$ \\
\hline O. funerea & 5 & $302.17 \pm 29.53$ & $106.5 \pm 14.21$ & $2.85 \pm 0.15$ & $4-6$ & $116.5 \pm 12.87$ & $89.83 \pm 11.41$ \\
\hline O. dianica & 6 & $567.33 \pm 70.22$ & $176.67 \pm 19.31$ & $3.21 \pm 0.70$ & $5-6$ & $155.33 \pm 10.16$ & $115.83 \pm 10.91$ \\
\hline O. dianica & 7 & $570 \pm 84.12$ & $185.83 \pm 21.74$ & $3.06 \pm 0.16$ & $5-6$ & $155 \pm 13.58$ & $105.33 \pm 14.32$ \\
\hline O. fusca & 8 & $368.17 \pm 53.38$ & $153 \pm 18.08$ & $2.41 \pm 0.45$ & $4-6$ & $130 \pm 9.10$ & $100.67 \pm 7.96$ \\
\hline O. lutea & 9 & $247.67 \pm 42.32$ & $142.17 \pm 20.12$ & $1.74 \pm 0.41$ & $4-6$ & $130.5 \pm 14.28$ & $106 \pm 11.92$ \\
\hline O. sicula & 10 & $327.67 \pm 35.13$ & $89.17 \pm 12.18$ & $3.67 \pm 0.67$ & $5-7$ & $122 \pm 10.95$ & $69 \pm 7.70$ \\
\hline O. vasconica & 11 & $350.90 \pm 56.58$ & $150.57 \pm 24.74$ & $2.40 \pm 0.58$ & $4-6$ & $124.35 \pm 13.78$ & $87.05 \pm 13.78$ \\
\hline O. speculum & 12 & $325 \pm 25.26$ & $114.83 \pm 10.13$ & $2.83 \pm 0.29$ & $5-6$ & $106.83 \pm 7.71$ & $84.5 \pm 8.34$ \\
\hline O. tenthredinifera & 13 & $483.83 \pm 60.51$ & $145.17 \pm 11.56$ & $3.33 \pm 0.51$ & $5-7$ & $129.5 \pm 12.48$ & $93.5 \pm 11.61$ \\
\hline O. bombyliflora & 14 & $415.21 \pm 35.62$ & $129.57 \pm 15.96$ & $3.25 \pm 0.50$ & $5-7$ & $110.52 \pm 28.98$ & $77.99 \pm 22.77$ \\
\hline O. insectifera & 15 & $481 \pm 55.04$ & $146.67 \pm 17.68$ & $3.28 \pm 0.41$ & $5-7$ & $132.33 \pm 11.04$ & $103.33 \pm 7.80$ \\
\hline O. apifera & 16 & $495.17 \pm 79.97$ & $140.83 \pm 11.22$ & $3.52 \pm 0.57$ & $5-7$ & $131 \pm 10.78$ & $101.17 \pm 8.97$ \\
\hline O. chestermanii & 17 & $740.33 \pm 98.92$ & $174.82 \pm 25.26$ & $4.30 \pm 0.73$ & $6-8$ & $161.24 \pm 22.40$ & $114.89 \pm 15.98$ \\
\hline O. scolopax & 18 & $560.83 \pm 92.35$ & $171.5 \pm 28.53$ & $3.27 \pm 0.10$ & $4-6$ & $153.5 \pm 27.86$ & $120.33 \pm 23.37$ \\
\hline O. morisii & 19 & $516.83 \pm 42.35$ & $164.83 \pm 19.14$ & $3.13 \pm 0.43$ & $4-6$ & $159.5 \pm 14.70$ & $119.33 \pm 11.50$ \\
\hline O. castellana & 20 & $306.33 \pm 52.31$ & $136.17 \pm 19.55$ & $2.25 \pm 0.49$ & $5-7$ & $101.67 \pm 9.85$ & $83.33 \pm 7.58$ \\
\hline O. incubacea & 21 & $518.49 \pm 62.01$ & $135.53 \pm 17.47$ & $3.87 \pm 0.59$ & $6-8$ & $122.89 \pm 11.57$ & $83.74 \pm 12.88$ \\
\hline O. sphegodes & 22 & $322.02 \pm 50.83$ & $125.23 \pm 17.16$ & $2.59 \pm 0.38$ & $4-6$ & $131.67 \pm 21.51$ & $88.38 \pm 15.84$ \\
\hline
\end{tabular}


Table 3. Average values of seed and embryo volumes, percentage of free air space, and colour of the testa of the taxa analysed.

\begin{tabular}{|c|c|c|c|c|c|}
\hline Species & Code & seed volume $\left(\mathrm{mm}^{3}\right)$ & embryo volume $\left(\mathrm{mm}^{3}\right)$ & $\%$ free air space & Colour \\
\hline O. dyris & 1 & $7.47 \pm 1.65$ & $0.98 \pm 0.24$ & $86.83 \pm 3.66$ & Brown \\
\hline O. dyris & 2 & $5.64 \pm 1.66$ & $0.92 \pm 0.25$ & $83.65 \pm 5.63$ & Brown \\
\hline O. eleonorae & 3 & $4.01 \pm 0.99$ & $1.08 \pm 0.50$ & $73.01 \pm 12.98$ & Brown-yellowish \\
\hline O. eleonorae & 4 & $4.64 \pm 1.32$ & $1.11 \pm 0.35$ & $73.01 \pm 12.98$ & Brown-yellowish \\
\hline O. funerea & 5 & $0.93 \pm 0.35$ & $0.51 \pm 0.18$ & $44.98 \pm 4.53$ & Dark brown \\
\hline O. dianica & 6 & $4.89 \pm 1.50$ & $1.11 \pm 0.29$ & $76.65 \pm 4.92$ & Brown \\
\hline O. dianica & 7 & $5.38 \pm 1.99$ & $0.93 \pm 0.31$ & $82.38 \pm 2.14$ & Brown \\
\hline O. fusca & 8 & $2.26 \pm 0.63$ & $0.69 \pm 0.14$ & $69.43 \pm 11.06$ & Brown \\
\hline O. lutea & 9 & $1.31 \pm 0.44$ & $0.77 \pm 0.23$ & $41.41 \pm 14.45$ & Dark brown \\
\hline O. sicula & 10 & $0.68 \pm 0.19$ & $0.31 \pm 0.07$ & $54.74 \pm 5.44$ & Dark brown \\
\hline O. vasconica & 11 & $2.10 \pm 0.67$ & $0.52 \pm 0.22$ & $72.84 \pm 15.20$ & Brown-yellowish \\
\hline O. speculum & 12 & $1.12 \pm 0.23$ & $0.40 \pm 0.10$ & $64.40 \pm 7.66$ & Dark brown \\
\hline O. tenthredinifera & 13 & $2.67 \pm 0.49$ & $0.59 \pm 0.17$ & $77.79 \pm 7.11$ & Brown-yellowish \\
\hline O. bombyliflora & 14 & $1.84 \pm 0.43$ & $0.42 \pm 0.29$ & $78.14 \pm 14.26$ & Brown-yellowish \\
\hline O. insectifera & 15 & $2.71 \pm 0.89$ & $0.75 \pm 0.17$ & $71.24 \pm 8.18$ & Brown-yellowish \\
\hline O. apifera & 16 & $2.60 \pm 0.64$ & $0.70 \pm 0.17$ & $73.01 \pm 6.49$ & Brown \\
\hline O. chestermanii & 17 & $6.09 \pm 2.01$ & $1.13 \pm 0.33$ & $79.98 \pm 7.09$ & Brown-yellowish \\
\hline O. scolopax & 18 & $4.66 \pm 2.32$ & $1.29 \pm 0.75$ & $72.97 \pm 4.72$ & Brown \\
\hline O. morisii & 19 & $3.67 \pm 0.96$ & $1.19 \pm 0.30$ & $67.65 \pm 9.04$ & Brown-yellowish \\
\hline O. castellana & 20 & $1.49 \pm 0.60$ & $0.38 \pm 0.10$ & $72.17 \pm 11.86$ & Brown-yellowish \\
\hline O. incubacea & 21 & $2.55 \pm 0.76$ & $0.47 \pm 0.16$ & $80.99 \pm 6.11$ & Brown-yellowish \\
\hline O. sphegodes & 22 & $1.37 \pm 0.49$ & $0.56 \pm 0.24$ & $58.00 \pm 12.83$ & Brown-yellowish \\
\hline
\end{tabular}

(Averyanov, 1990), Anacamptis and Orchis (Gamarra \& al., 2012), the qualitative data observed in seeds do not support the distinction of infrageneric levels.

According to our statistical results two large clusters, based on the size of seed and embryo volumes, have been found. These clusters appear subdivided into six minor groups. Taxa of the sections Pseudophrys and Ophrys appear in both clusters, although a great number of the taxa analysed in the section Ophrys showed lower volumes. Furthermore, species ascribed to the same group by Delforge (2006) appear

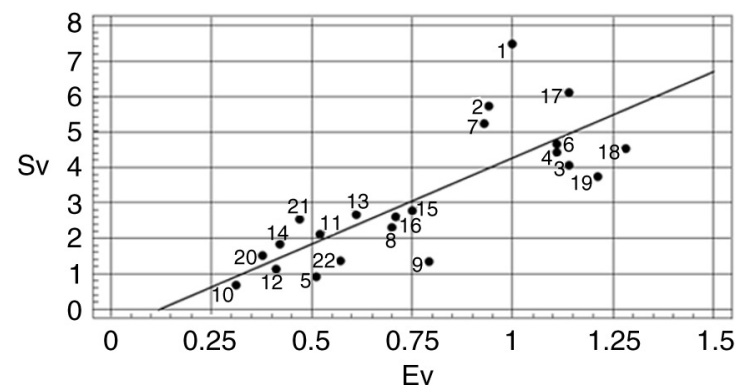

Fig. 3. Scatter plot showing the relation between seed volume (Sv) and embryo volume (Ev) in Ophrys seed. Dot numbers: 1, 2 O. dyris; 3, 4 O. eleonorae; 5 O. funerea; 6, 7 O. dianica; 8 O. fusca; 9 O. lutea; 10 O. sicula; 110 . vasconica; 12 O. speculum; 13 O. tenthredinifera; 14 O. bombyliflora; 150 . insectifera; 16 O. apifera; 17 O. chestermanii; 18 O. scolopax; 19 O. morisii; 20 O. castellana; 21 O. incubacea; 220. sphegodes. in different groupings in our clusters, such as O. bombyliflora and $O$. tenthredinifera, or O. castellana and O. incubacea. Our results are not congruent with the minor clades obtained by molecular analysis of the genus Ophrys (Soliva \& al., 2001; Bateman \& al., 2003; Bernardos \& al., 2005).

According to previous molecular analyses (Bateman \& al., 2003; Inda \& al., 2012), genera of the subtribe Orchidinae such as Serapias or Neotinea Rchb. fil., with higher bootstrap values, show a common micromorphological pattern of testa

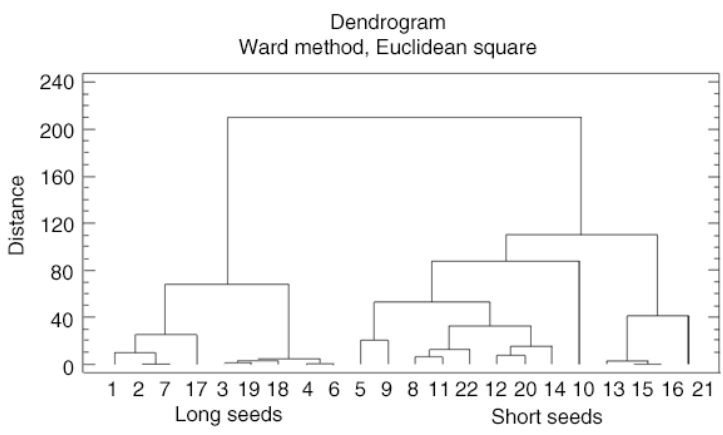

Fig. 4. Dendrogram showing the clustering of the taxa analysed. Ward's method was used to determine the Euclidean distance. Explanation of plot numbers: 1,2 O. dyris; 3,4 O. eleonorae; 50 . funerea; 6,7 0. dianica; 8 O. fusca; 9 O. lutea; 10 0. sicula; 11 0. vasconica; 12 O. speculum; 13 O. tenthredinifera; 14 O. bombyliflora; 15 O. insectifera; 16 O. apifera; 17 O. chestermanii; 18 O. scolopax; 19 O. morisii; 20 O. castellana; 21 O. incubacea; 22 O. sphegodes. 
cells (Barthlott, 1976; Gamarra \& al., 2007). On the opposite, in genera such as Anacamptis, Orchis and Dactylorbiza, with lower bootstrap values, the testa cells show qualitative differences which allow recognition of infrageneric groups (Averyanov, 1990; Gamarra \& al., 2012). In the genus Ophrys, our results are congruent with the high bootstrap value obtained by Bateman \& al. (2003) and Inda \& al. (2010). In contrast with the species richness and the high diversity of floral characters, the homogeneous micromorphological pattern of testa cells found in Ophrys is also supportive of the recent radiation and rapid colonization proposed for the evolution of this genus along the Mediterranean basin (Soliva \& al., 2001; Amich \& al., 2007).

\section{ACKNOWLEDGMENTS}

Technical assistance of the staff (Esperanza Salvador, Enrique Rodríguez and Isidoro Poveda) in the SEM laboratory at SIDI-UAM is gratefully acknowledged. Also, we thank our collaborators Iris Esparza and Ernesto Sanz who measured the quantitative data of some taxa.

\section{REFERENCES}

Amich, F., García-Barriuso, M. \& Bernardos, S. 2007. Polyploidy and speciation in the orchid flora of the Iberian Peninsula. Botanica Helvetica 117: 143-157. http://dx.doi.org/10.1007/s00035-007-0804-0.

Arditti, J., Michaud, J.D. \& Healey, P.L. 1979. Morphometry of orchid seeds. I. Paphiopedilum and native California and related species of Cypripedium. American Journal of Botany 66: 1128-1137. http://dx.doi. org $/ 10.2307 / 2442211$.

Arditti, J. \& Ghani, A.K.A. 2000. Numerical and physical properties of orchid seeds and their biological implications. New Phytologist 145: 367-421. http://dx.doi.org/10.1046/j.1469-8137.2000.00587.x.

Averyanov, L.V. 1990. A review of the genus Dactylorbiza. In: Arditti, J. (ed.), Orchid Biology. Reviews and Perspectives. 5: 159-206. Timber Press, Portland.

Aybeke, M. 2007. Pollen and seed morphology of some Ophrys L. (Orchidaceae) taxa. Journal of Plant Biology 50: 387-395. http://dx.doi. org/10.1007/BF03030673.

Barthlott, W. 1976. Morphologie der Samen von Orchideen im Hinblick auf taxonomische und funktionelle Aspekte. In: Senghas, K. (ed.), Proceedings of the $8^{\text {th }}$ World Orchid Conference Frankfurt 444-455. Parey, Hamburg.

Barthlott, W. \& Ziegler, B. 1981. Mikromorphologie der Samenschalen als systematisches Merkmal bei Orchideen. Berichte der Deutschen Botanischen Gesellschaft 94: 267-273.

Bateman, R.M., Hollingsworth, P.M., Preston, J., Yi-bo, L., Pridgeon, A.M., Chase, M.W. 2003. Molecular phylogenetics and evolution of Orchidinae and selected Habenariinae (Orchidadeae). Botanical Journal of the Linnean Society 142: 1-40. http://dx.doi.org/10.1046/j.1095-8339.2003.00157.x.

Baumann, H. \& Künkele, S. 1986. Die Gattung Ophrys L. - eine taxonomische Übersicht. Mitteilungen Arbeitskreis Heimische Orchideen Baden-Württemberg 16: 633-663.

Bernardos, S., Crespí, A., Del Rey, F. \& Amich, F. 2005. The section Pseudophrys (Ophrys, Orchidaceae) in the Iberian Peninsula: a morphometric and molecular analysis. Botanical Journal of the Linnean Society 148: 359-375. http://dx.doi.org/10.1111/j.1095-8339.2005.00403.x.

Clifford, H.T. \& Smith, W.K. 1969. Seed morphology and classification of Orchidaceae. Phytomorphology 19: 133-139.

D’Emerico, S., Pignone, D., Bartolo, G., Pulvirenti, S., Terrasi, C., Stuto, S. \& Scrugli, A. 2005. Karyomorphology, heterochromatin patterns and evolution in the genus Ophrys (Orchidaceae). Botanical Journal of the Linnean Society 148: 87-99. http://dx.doi.org/10.1111/j.1095-8339.2005.00393.x.
Del Prete, C. 1984. The genus Ophrys L. (Orchidaceae): a new taxonomic approach. Webbia 38: 209-220. http://dx.doi.org/10.1080/00837792. 1984.10670307

Delforge, P. 2006. Orchids of Europe, North Africa and the Middle East, 3rd ed. A\&C Black, London.

Devillers, P. \& Devillers-Terschuren, J. 1994. Essai d'analyse systématique du genre Ophrys. Naturalistes Belges (Orchid. 7, suppl.) 75: 273-400.

Gamarra, R., Dorda, E., Scrugli, A., Galán, P. \& Ortúñez, E. 2007. Seed micromorphology in the genus Neotinea Rchb.f. (Orchidaceae, Orchidinae). Botanical Journal of the Linnean Society 153: 133-140. http://dx.doi.org/10.1111/j.1095-8339.2006.00603.x.

Gamarra, R., Galán, P., Herrera, I. \& Ortúñez, E. 2008. Seed micromorphology supports the splitting of Limnorchis from Platanthera (Orchidaceae). Nordic Journal of Botany 26: 61-65. http://dx.doi.org/ 10.1111/j.1756-1051.2008.00135.x.

Gamarra, R., Ortúñez, E., Galán Cela, P. \& Guadaño, V. 2012. Anacamptis versus Orchis (Orchidaceae): seed micromorphology and its taxonomic significance. Plant Systematics and Evolution 298: 597-607. http:// dx.doi.org/10.1007/s00606-011-0569-1.

Godfery, M.J. 1928. Classification of the genus Ophrys. Journal of Botany 66: $33-36$.

Greilhuber, J. \& Ehrendorfer, F. 1975. Chromosome numbers and evolution in Ophrys (Orchidaceae). Plant Systematics and Evolution 124: 125. 138. http://dx.doi.org/10.1007/BF00985498.

Inda, L.A., Pimentel, M. \& Chase, M.W. 2010. Contribution of mitocondrial cox1 intron sequences to the phylogenetics of tribe Orchideae (Orchidaceae): Do the distribution and sequence of this intron in orchids also tell us something about its evolution? Taxon 59(4): 1053-1064. http://dx.doi.org/10.2307/20773976.

Inda, L.A., Pimentel, M. \& Chase, M.W. 2012. Phylogenetics of tribe Orchideae (Orchidaceae; Orchidoideae) based on combined DNA matrices: inferences regarding timing of diversification and evolution of pollination syndromes. Annals of Botany 110: 71-90. http://dx.doi.org/ $10.1093 / \mathrm{aob} / \mathrm{mcs} 083$

Molvray, M. \& Kores, P.J. 1995. Character analysis of the seed coat in Spiranthoideae and Orchidoideae, with special reference to the Diurideae (Orchidaceae). American Journal of Botany 82: 1443-1454. http://dx.doi.org/10.2307/2445872.

Mrkvicka, A.C. 1994. Anatomie und Morphologie der Samen heimischer Orchideenarten. Journal Europäischer Orchideen 26: 168-314.

Nelson, E. 1962. Gestaltwandel und Artbildung erörtert am Beispiel der Orchidaceen Europas und der Mittelmeerländer insbesondere der Gattung Ophrys - mit einer Monographie und Ikonographie der Gattung Ophrys. Verlag E. Nelson, Chernex-Montreux.

Paulus, H.F. \& Gack, C. 1990. Pollinators as prepollinating isolation factors: evolution and speciation in Ophrys (Orchidaceae). Israel Journal of Botany 39: 43-79.

Pedersen, H.A. \& Faurholdt, N. 2007. Ophrys. The bee orchids of Europe. Kew Publishing, Royal Botanic Gardens, Kew.

Pridgeon, A.M., Cribb, P.J., Chase, M.W. \& Rasmussen, F.N. 2001. Genera Orchidacearum. Volume 2. Orchidoideae (part one). Oxford University Press, Oxford.

Soliva, M., Kocyan, A. \& Widmer, A. 2001. Molecular phylogenetics of the sexually deceptive orchid genus Ophrys (Orchidaceae) based on nuclear and chloroplast DNA sequences. Molecular Phylogenetics and Evolution 20: 78-88. http://dx.doi.org/10.1006/mpev.2001.0953.

Thiers, B. 2012. Index Herbariorum: A global directory of public herbaria and associated staff. New York Botanical Garden's Virtual Herbarium. http://sweetgum.nybg.org/ih/ [continuously updated; accessed September 2012]

Tohda, H. 1983. Seed morphology in Orchidaceae I. Dactylorchis, Orchis, Ponerorchis, Chondradenia and Galeorchis. Science Reports of the Toboku University, 4th ser., Biology 38: 253-268.

Associate Editor: Javier Fuertes Received: $11-\mathrm{V}-2013$ Accepted: 8-XI-2014 